\title{
THE EFFECT OF NON-STARCH POLYSACCHARIDES DERIVED FROM DIFFERENT GRAINS ON PERFORMANCE AND DIGESTIVE ACTIVITY IN LAYING HENS
}

\author{
S. Hartini ${ }^{1}$ and M. Choct $^{2}$ \\ ${ }^{1}$ Faculty of Animal Husbandry, Fishery and Marine Science, \\ Papua State University, \\ Jl. Gunung Salju, Amban, Manokwari 98314, Papua Barat - Indonesia. \\ ${ }^{2}$ School of Rural Science and Agriculture, \\ University of New England, Armidale, NSW - Australia 2351 \\ Corresponding E-mail : shartini2003@yahoo.com
}

Received March 2, 2010; Accepted May 12, 2010

\begin{abstract}
An experiment was conducted to observe the effect of non-starch polysaccharides (NSP) on performance and digestive activity of laying hens. Thirty-two ISA Brown hens were individually caged and offered four diets (wheat-based, millrun-based, barley-based, and barley-enzymes diets) for 10 weeks. The present experiment was assigned in a completely randomized design with 8 replicates per dietary treatment. Wheat- and barley diets caused significantly higher $(\mathrm{P}<0.05)$ viscosity than other diets. Increased viscosity caused lower digesta dry matter $(\mathrm{DM})(\mathrm{P}<0.01)$ and higher excreta moisture $(\mathrm{P}<0.05)$. The wheat diet did not cause a negative effect on intestinal starch digestibility, feed intake, and bird performance $(\mathrm{P}>0.05)$. Birds fed the barley-based diet had lower weight gain $(\mathrm{P}<0.05)$ and higher caecal weight $(\mathrm{P}<0.05)$ than those given other diets. Enzyme supplementation on barley diets significantly $(\mathrm{P}<0.05)$ reduced jejunal digesta viscosity and caecal weight, increased weight gain $(\mathrm{P}<0.05)$ and ileal digesta DM $(\mathrm{P}<0.01)$, and numerically reduced excreta moisture. The current study demonstrated that NSP have a profound effect on digesta viscosity, performance, and digestive organs of birds; however, the NSP action may be modified by an interaction with each other and with other cellwall components of grains in the gut. Enzyme supplementation reduced the negative effect of digesta viscosity.

Keyword: digestive organs, digesta viscosity, enzyme supplementation, laying hens, NSP
\end{abstract}

\section{INTRODUCTION}

The use of wheat, rye, oats, or barley in diets for monogastric animals is constrained by the fact that soluble non-starch polysaccharides (NSP) such as; arabinoxylans from wheat or rye, or $\beta$ glucans from barley or oats increase digesta viscosity which negatively impacts bird performance. The gel-like environment caused by increased viscosity may trap nutrients and digestive enzymes, hence impairing the mixing of digestive enzymes with their substrates. Wheat NSP given to broiler was found to inhibit nutrient digestion such as starch and protein, and eventually depressed growth rate (Annison, 1993; Choct et al., 1999). A decreased in body weight (BW), feed intake (FI), and an increased in feed convertion ratio (FCR) were found in broiler chickens fed barley-based diet (Shakouri et al.,
2009). In addition, the birds on the barley-based diet had lower ileal digestibility of dry matter, protein and energy than those given maize and sorghum-based diets (Shakouri et al., 2009). Birds compensate for the apparent decrease in the rate of nutrient absorption as well as an increased need for enzymes by enlarging pancreas and digestive organ size (Hartini, 1996). Enzyme supplementation of the NSP-enriched diet reduced ileal digesta viscosity, and increased ileal starch digestibility, feed intake, and weight gain (Choct et al., 1999; Shakouri et al., 2009).

In contrast to soluble NSP, insoluble NSP has been reported as having beneficial effect on nutrient utilization. Indeed, starch digestibility was increased in birds fed wheat-based diets diluted with cellulose (Svihus and Hetland, 2001) or oat hulls (Hetland et al., 2003). Digestibility of starch is higher when a moderate level of 
insoluble fibre is present in the diet (Hetland et $a l ., 2004)$. In addition, insoluble fibre was found to modulate the cannibalism behaviour of laying hens (Hartini et al., 2002).

Although the results of feeding NSP appear similar across and within species, differences in digestive functions are likely to affect at least the degree of response. Furthermore, the NSP content can vary among different cereals, or among individuals of the same variety, which subsequently will influence its physiological activities in the gut. Indeed, recent research demonstrated that there is large variation in soluble NSP among 30 wheat cultivars (McCracken et al., 2008). Therefore, the current study was conducted to observe the effect of NSP from different types and sources of dietary fibre on digesta viscosity, performance, starch digestibility, and digestive organs measurements in laying hens.

\section{MATERIALS AND METHODS}

\section{Experimental diets and animals}

Four diets, namely wheat-based $(672 \mathrm{~g} / \mathrm{kg}$ of wheat); millrun-based; barley-based $(646.8 \mathrm{~g} / \mathrm{kg}$ of barley), and barley + enzyme ( $\beta$-glucanase) diets were used in this experiment. Wheat- and barley-based diets represented soluble dietary fibres, whereas millrun-based diet represented insoluble dietary fibre. Thirty-two commercial strains of ISA Brown hens at 32 weeks of age were individually caged and were randomly allocated to four dietary treatments, giving 8 replicate birds per diet. Birds were given the experimental diets for 10 weeks. All diets were formulated to be isonitrogenous and approximately isocaloric (Table 1). Alkane $\mathrm{C}_{36} \mathrm{H}_{74}$ (400 $\mathrm{mg} / \mathrm{kg}$ ) was added to four diets as a digestibility marker. Feed and water were available ad libitum.

\section{Variables measurement}

During the experiment, average weight gain (g) and feed intake (g/bird/day) and hen-day egg production (HDEP, \%) were recorded and feed: egg ratio $(\mathrm{kg} / \mathrm{kg})$ was calculated. Excreta were collected daily for measurement of dry matter content. Dry matter of excreta was determined following drying at $80^{\circ} \mathrm{C}$ for $72 \mathrm{~h}$.

At the end of the experiment, birds were weighed and killed by cervical dislocation. The body cavity was opened and gastrointestinal tract, including gizzard, was removed and cut into
Table 1. Composition of Experimental Diets (\%

\begin{tabular}{lcccc}
\hline \multicolumn{1}{c}{$\quad$ Ingredients } & Wheat & Millrun & Barley & Barley + \\
& & & & enzy me \\
\hline Wheat & 67.2 & - & - & - \\
Millrun & - & 32 & - & - \\
Sorghum & - & 42.31 & - & - \\
Barley & - & - & 64.68 & 64.68 \\
Oil & - & 3.5 & 2.25 & 2.25 \\
Meat meal & 10 & 10.5 & 10.5 & 10.5 \\
Mung beans & 6.75 & - & - & - \\
Soybean meal & - & 5 & 7 & 7 \\
Cottonseed meal & 2.7 & - & 4 & 4 \\
Rice pollard & 6.75 & - & 5.25 & 5.25 \\
Limestone & 6 & 5.75 & 5.75 & 5.75 \\
Salt & 0.1 & 0.11 & 0.12 & 0.12 \\
Choline chloride & 0.03 & 0.03 & 0.03 & 0.03 \\
DL-methionine & 0.08 & 0.15 & 0.07 & 0.07 \\
L-Lysine & 0.05 & 0.3 & - & - \\
Layer/pullet premix & 0.2 & 0.2 & 0.2 & 0.2 \\
Synthetic yolk & & & & \\
color premix & 0.15 & 0.15 & 0.15 & 0.15 \\
Chemical comp onent. & & & & \\
ME, M J/kg & 11.7 & 11.3 & 11.3 & 11.3 \\
Crude Protein, \% & 17 & 17 & 17 & 17 \\
Fat, \% & 3.8 & 7.11 & 5.74 & 5.74 \\
Crude Fibre, \% & 3.19 & 4.4 & 5.63 & 5.63 \\
Methionine, \% & 0.32 & 0.38 & 0.32 & 0.32 \\
Ly sine, \% & 0.75 & 0.96 & 0.11 & 0.11 \\
Calcium, \% & 3.51 & 3.48 & 3.49 & 3.49 \\
Non-phytate & & & & \\
Phosphorus, \% & 0.54 & 0.57 & 0.56 & 0.56 \\
Sodium, \% & 0.15 & 0.15 & 0.15 & 0.15 \\
\hline A & & & &
\end{tabular}

A commercial $\beta$-glucanase added at $300 \mathrm{~g} /$ tonne

(Novozymes Pty Ltd, Australia)

segments, viz gizzard, jejunum, ileum and caeca. The gastrointestinal sections were weighed prior to and after removal of digesta. The empty section weights were expressed as a percentage of body weight $(\% \mathrm{BW})$. The digesta samples collected were used to analyse DM, viscosity, starch and alkane contents.

Dry matter of the digesta was determined using a drying oven at $105^{\circ} \mathrm{C}$ for $24 \mathrm{~h}$. Digesta viscosity (in $\mathrm{mPa} . \mathrm{s}$ ) were analysed using Brookfield DVIII viscometer maintained at $25^{\circ} \mathrm{C}$ with a CP40 cone and a shear rate of 5-500 s $\mathrm{s}^{-1}$. Alkane content of digesta was measured as per Choct and Barneveld (1995), and starch content of digesta was determined using Megazyme total starch kit (AA/AMG 9/97) based on the method developed by McCleary et al. (1994).

Digestibility of starch (\%) was calculated using the following equation: 
Digestibility $(\%)=$

$$
\left(1-\frac{\text { digesta nutrient/digesta alkane }}{\text { diet nutrient/diet alkane }}\right) \times 100
$$

\section{Statistical Analysis}

Data were analyzed using general linear model procedure for ANOVA appropriate for completely randomized design (Manugistics, Inc., Rockville, MD) to determine the effect of dietary treatment. When the significant $\mathrm{F}$ test $(\mathrm{P}<0.05)$ was observed, it was continued with Duncan's multiple-range test to inspect significant differences $(\mathrm{P}<0.05)$ among means of dietary teatment.

\section{RESULTS}

\section{Digesta viscosity and bird performance}

The wheat diet caused higher digesta viscosity $(\mathrm{P}<0.01)$ both in the jejunum and ileum (Table 2). Birds fed the barley diet had markedly $(\mathrm{P}<0.01)$ higher digesta viscosity in jejunum, but their digesta viscosity in the ileum was not different from those given the millrun diet. Diets had no significant effect on feed intake, feed:egg ratio and \% HDEP (Table 2). Birds fed the wheat diet had a higher $(\mathrm{P}<0.05)$ weight gain than those fed other diets. Enzyme addition to the barley diet reduced jejunal digesta viscosity $(\mathrm{P}<0.01)$ and increased weight gain $(\mathrm{P}<0.05)$.

\section{Starch digestibilities, gastrointestinal measurements, and dry matter digesta}

Diets had a significant effect $(\mathrm{P}<0.05)$ on the digestibility of starch in the ileum (Table 2). Birds fed the barley and barley-enzyme diets had the highest starch digestibility in the ileum, whereas those fed the wheat diet had the lowest. The effect of diets on the weight of gizzard, jejunal, and ileal digesta was not significantly different $(\mathrm{P}>0.05$, Table 2). Results on empty gastrointestinal weight also showed that only the caecal weight $(\% \mathrm{BW})$ was affected by diet, with the barley diet caused the heaviest caeca $(\mathrm{P}<0.05$, Table 2). Enzyme addition to the barley diet reduced $(\mathrm{P}<0.05)$ the caecal weight.

Digesta $\mathrm{DM}$ of the jejunum and ileum was significantly $(\mathrm{P}<0.01)$ affected by diets (Table 2$)$. Birds on the millrun diet had higher digesta DM in the jejunum than those on other diets, which were not significantly different. Ileal digesta DM in birds fed the millrun and barley + enzyme diets was higher than that in those fed other diets, whereas the ileal digesta DM in birds fed the wheat diet was the lowest $(\mathrm{P}<0.01)$. Enzyme addition to the barley diet increased the ileal digesta DM $(\mathrm{P}<0.01)$.

Results on excreta moisture showed that birds fed the barley diet had lower excreta moisture $(\mathrm{P}<0.05$, Table 2$)$ than those fed wheat and millrun diets. Enzyme addition to the barley diet numerically reduced the moisture content of the excreta.

\section{DISCUSSION}

Increased intestinal viscosity depressed nutrient digestibility and impaired bird performance, and addition of enzymes with the ability to cleave the large molecules of NSP into smaller polymers would overcome the problems (Choct et al., 1999, Shakouri et al., 2009). In the current study, birds fed the wheat diet had higher digesta viscosity in the jejunum and ileum; whereas birds fed the barley diet only had higher viscosity in the jejunum. These findings indicate that depolymerisation of cell wall NSP in birds fed the wheat diet probably occurred throughout the intestine. A previous study in rye-fed birds observed that cell-wall carbohydrates continue to be released during transit through the small intestine (Bedford and Classen, 1992), resulting in increased digesta viscosity. Increased intestinal viscosity was also reflected by the lower digesta DM and the higher excreta moisture. This is in agreement with the finding by Choct (1997) who found an increase in excreta moisture due to addition of soluble NSPs to a sorghum-based broiler diet. Addition of enzyme to barley-based diet only tended to reduce the excreta moisture. This result also supported the view by Choct (1997) that enzymes have a similar beneficial effect in monogastric animals but the site in which the enzyme breakdown the NSP in the gut and the molecular sizes of the released product differ. Thus, effect of enzyme addition in reducing excreta moisture also differs.

It could have been expected that increased intestinal viscosity in birds fed the wheat diets would result in reduced feed intake, nutrient digestibility and impaired bird performance. However, the results showed that increased intestinal viscosity in birds fed the wheat diet did not have a negative effect on intestinal starch digestibilities, feed intake, egg production and body weight gain. The result supported the finding by Lazaro et al. (2003) that the use of 
Table 2. Performance, Digesta Viscosity, Starch Digestibility and Digestive Organ Measurements (Mean \pm SEM) of Laying Hens Fed Different Diets

\begin{tabular}{|c|c|c|c|c|c|}
\hline & Wheat & Millrun & Barley & Barley+enzyme & $\operatorname{Sig}^{1}$ \\
\hline Average weight gain $(\mathrm{g})$ & $74 \pm 4.4^{\mathrm{a}}$ & $66 \pm 4.4^{\mathrm{ab}}$ & $54 \pm 4.4^{b}$ & $66 \pm 4.4^{\mathrm{ab}}$ & $*$ \\
\hline Feed intake (g/bird/d) & $165 \pm 5.8$ & $169 \pm 5.8$ & $155 \pm 5.8$ & $155 \pm 5.8$ & ns \\
\hline Feed:Egg ratio $(\mathrm{kg} / \mathrm{kg})$ & $2.4 \pm 5.8$ & $2.4 \pm 5.8$ & $2.2 \pm 5.8$ & $2.2 \pm 5.8$ & ns \\
\hline HDEP $(\%)$ & $89 \pm 4.1$ & $83 \pm 3.8$ & $83 \pm 4.4$ & $76 \pm 4.4$ & ns \\
\hline Jejunal digesta viscosity (mPa.s) & $3.2 \pm 0.2^{\mathrm{a}}$ & $2.3 \pm 0.2^{b}$ & $3.0 \pm 0.2^{\mathrm{a}}$ & $2.0 \pm 0.2^{b}$ & $* *$ \\
\hline Ileal digesta viscosity (mPa.s) & $9.5 \pm 0.8^{\mathrm{a}}$ & $5.6 \pm 0.9^{b}$ & $4.8 \pm 0.8^{b}$ & $3.5 \pm 0.8^{b}$ & $* *$ \\
\hline Jejunal starch digestibility (\%) & $90 \pm 4.3$ & $82 \pm 4.3$ & $96 \pm 4.3$ & $97 \pm 4.3$ & ns \\
\hline Ileal starch digestibility (\%) & $92 \pm 1.9^{b}$ & $96 \pm 1.9^{a b}$ & $98 \pm 1.9^{a}$ & $99 \pm 1.9^{a}$ & $*$ \\
\hline Gizzard digesta $(\mathrm{g})$ & $4.7 \pm 0.6$ & $3.7 \pm 0.7$ & $4.8 \pm 0.7$ & $3.6 \pm 0.7$ & ns \\
\hline Jejunal digesta $(\mathrm{g})$ & $14.8 \pm 1.9$ & $13.3 \pm 1.9$ & $10.4 \pm 1.9$ & $8.0 \pm 1.9$ & ns \\
\hline Ileal digesta $(\mathrm{g})$ & $16.5 \pm 2.2$ & $16.8 \pm 2.2$ & $14.8 \pm 2.2$ & $15.7 \pm 2.2$ & ns \\
\hline Caecal digesta $(\mathrm{g})$ & $5.3 \pm 0.6$ & $4.6 \pm 0.6$ & $4.4 \pm 0.6$ & $5.9 \pm 0.6$ & ns \\
\hline Empty gizzard weight (\% BW) & $1.3 \pm 0.1$ & $1.3 \pm 0.1$ & $1.5 \pm 0.1$ & $1.4 \pm 0.1$ & ns \\
\hline Empty jejunal weight (\%BW) & $1.2 \pm 0.1$ & $1.2 \pm 0.1$ & $1.2 \pm 0.1$ & $1.1 \pm 0.1$ & ns \\
\hline Empty ileal weight (\%BW) & $0.9 \pm 0.1$ & $0.9 \pm 0.1$ & $0.9 \pm 0.1$ & $0.8 \pm 0.1$ & ns \\
\hline Empty caecal weight (\%BW) & $0.5 \pm 0.0^{\mathrm{b}}$ & $0.5 \pm 0.0^{\mathrm{b}}$ & $0.6 \pm 0.0^{\mathrm{a}}$ & $0.5 \pm 0.0^{b}$ & $*$ \\
\hline Jejunal digesta DM (\%) & $19.5 \pm 0.4^{\mathrm{b}}$ & $22.9 \pm 0.4^{\mathrm{a}}$ & $19.7 \pm 0.4^{\mathrm{b}}$ & $20.4 \pm 0.4^{\mathrm{b}}$ & $* *$ \\
\hline Ileal digesta DM (\%) & $21.9 \pm 0.5^{\mathrm{c}}$ & $27.5 \pm 0.5^{\mathrm{a}}$ & $23.9 \pm 0.5^{b}$ & $26.2 \pm 0.5^{\mathrm{a}}$ & $* *$ \\
\hline Caecal digesta DM (\%) & $20.4 \pm 1.6$ & $25.8 \pm 1.6$ & $20.6 \pm 1.6$ & $20.1 \pm 1.6$ & ns \\
\hline Excreta moisture (\%) & $78.7 \pm 2.1^{\mathrm{a}}$ & $78.7 \pm 2.1^{\mathrm{a}}$ & $75.9 \pm 2.1^{\mathrm{ab}}$ & $70.6 \pm 2.1^{\mathrm{b}}$ & $*$ \\
\hline
\end{tabular}

a-c: mean values within a row with different superscripts indicate differ significantly $(\mathrm{P}<0.05)$.

$1 *=$ signific ant $(\mathrm{P}<0.05) ; * *=$ highly significant $(\mathrm{P}<0.01) ; \mathrm{ns}=$ not signific ant

soluble fibre cereals in the laying hen diet instead of maize did not affect egg production or food efficiency. Furthermore, these results were not surprising considering the viscosity of birds fed the wheat diet was low. In the current study, intestinal viscosity in birds fed the wheat diet and barley diet was below $10 \mathrm{mPa}$.s. Cowan (1995) found that gut viscosity below approximately 10 $\mathrm{mPa}$.s would not depress performance, and birds can tolerate small increases in gut viscosity up to this threshold (Choct and Annison, 1992). Annison et al. (1995) found that soluble NSP of low viscosity had no effect on growth, feed convertion ratio, or the digestibilities of starch and protein. The millrun diet did not increase viscosity, indicating that this diet had no viscous properties. The fact that there was no compensatory intake on birds fed the millrun diet, suggests that the concentration of insoluble NSP on the millrun diet had little impact on dietary energy availability.
A high starch digestibility was observed in birds fed the barley diets, but the weight gain was the lowest compared to those fed other diets. Although the gut viscosity in barley-fed birds was considered low, the present of soluble NSP in the intestine of birds fed the barley diet could stimulate the development of gut microflora, leading to increases in bacterial fermentation. Increased intestinal viscosity, as well as the present of undigested materials in the gut lead to increases not only in microbial numbers (Choct $e t$ al., 1992), but also in the overall microbial activity in the gut (Choct et al. 1996). Increased bacterial population and activity can reduce the utilization of nutrients, resulting in reduced performance.

Birds fed the barley diet also had the heaviest caecal weight. An increase in caecal weight was also observed in broilers fed soluble dietary gum (Hartini, 1996). Large numbers of microorganisms in poultry are found in caeca. The 
present of soluble NSP, as fermentative substrates may stimulate the development of bacterial population in the caeca, hence causing a modification of gut morphology. Indeed, the visceral organs including liver, jejunum, ileum and caecum of conventional birds are heavier than those of germ-free birds (Muramatsu et al., 1993). Enzyme addition to the barley diet improved weight gain and reduced caecal weight, this was probably due to elimination of fermentative substrates, and hence any microbial influence on the digestive tract of the birds (Choct et al., 1999; Shakouri et al., 2009). The results of this study suggest that the cause of decreased nutrient digestibility is not due to viscosity per se as stated by Smits et al. (1997), but also affected by the amount of fermentative substrates present in the gut.

\section{CONCLUSION}

The present study concluded that NSPs (soluble and insoluble) have a marked difference in their physiological effect such as digesta viscosity, starch digestibilities, and digestive organ measurements in the gut. The enzyme supplementation reduced the negative effect of digesta viscosity. Further research is needed to evaluate the effect of feeding NSP derived from different dietary fibres on the development of gut microorganism in laying hens.

\section{ACKNOWLEDGMENTS}

The experimental work presented was made possible through the financial assistance provided by the Egg Industry Program of the Rural Science and Research Development Program and the Australian Agency for International Development.

\section{REFERENCES}

Annison, G. 1993. The chemistry of dietary fiber. In: Samman, S. and G. Annison, eds. Dietary Fiber and Beyond-Australian Perspective. Nutrition Society of Australia Inc. Perth, Australia.

Annison, G., P. Moughan and D.V. Thomas. 1995. Nutritive activity of soluble rice bran arabinoxylans in broiler diets. Br. Poult. Sci. 36 (3):479-488.

Bedford, M.R and H. L. Classen. 1992. Reduction of intestinal viscosity through manipulation of dietary rye and pentosanase concentration is affected through changes in the carbohydrate composition of the intestinal aqueous phase and results in improved growth rate and feed conversion efficiency of broiler chickens. J. Nutr. 122: 560-569.

Choct, M. 1997. Enzyme in animal nutrition: the unseen benefits. In: Enzymes in Poultry and Swine Nutrition. (Marquardt, R.R. and Z. Han, eds). IDRC, Ontario. Canada. P. 45-52.

Choct, M. and G. Annison. 1992. Anti-nutritive effect of wheat pentosans in broiler chickens: roles of viscosity and gut microflora. $\mathrm{Br}$. Poult. Sci. 33:821-834.

Choct, M., G. Annison and R.P. Trimble. 1992. Soluble wheat pentosans exhibit different anti-nutritive activities in intact and cecectomized broiler chickens. J. Nutr. 122: 2457-2465.

Choct, M., R.J. Hughes and M.R. Bedford. 1999. Effects of a xylanase on individual bird variation, starch digestion throughout the intestine, and ileal and caecal volatile fatty acid production in chickens fed wheat. $\mathrm{Br}$. Poult. Sci. 40(3):419-422.

Choct, M., R.J. Hughes, J. Wang, M.R. Bedford, A.J. Morgan and G. Annison. 1996. Increased small intestinal fermentation is partly responsible for the anti-nutritive activity of non-starch polysaccharides in chickens. Br. Poult. Sci. 37:609-621.

Cowan, D. 1995. The relevance of intestinal viscosity on performance of practical broiler diets. Proceedings of the $7^{\text {th }}$ Australian Poultry Science Symposium. Sydney, Australia. 1995. P. 116-120.

Hartini, S. 1996. Effect of soluble dietary fiber on growth and digestive enzyme activity of broiler chickens. Indonesian J. Nutr. Feed Sci. 1: 13-20.

Hartini, S., M. Choct, G. Hinch, A. Kocher and J.V. Nolan. 2002. Effect of light intensity during rearing and beak trimming and dietary fiber sources on mortality, egg production, and performance of ISA Brown laying hens. J.Appl. Poult. Res. 11:104-110.

Hetland, H., M. Choct and B. Svihus. 2004. Role of insoluble non-starch polysaccharides in poultry nutirion (a review). World's Poult. Sci. J. 60: 415-422.

Hetland, H., B. Svihus and A. Krogdahl. 2003. Effects of oat hulls and wood shavings on digestion in broilers and layers fed diets based on whole or ground wheat. Br. Poult. Sci. 44: 275-282. 
Lázaro R, M. García, M.J. Araníbar, and G.G. Mateos. 2003. Effect of enzyme addition to wheat-, barley- and rye-based diets on nutrient digestibility and performance of laying hens. Br. Poult. Sci. 44(2): 256-265.

McCleary, B.V., V. Solah and T.S. Gibson. 1994. Quantitative measurement of total starch in cereal flours and products. J. Cereal Sci. 20: 51-58.

McCracken, K.J., B. Owens, R. Park. and J. McNab. 2008. Lack of relationship between either specific weight or presence of the 1B1R gene and nutritive value of wheat in broiler diets. Br. Poult. Sci. 49(4): 463-474.

Muramatsu, T. O. Takasu and J. Okumura. 1993.
Fructose feeding increases lower gut weight in germ-free and conventional chicks. Poult. Sci. 72: 1597-1600.

Shakouri M.D, P.A. Iji, L.L. Mikkelsen and A.J. Cowieson. 2009. Intestinal function and gut microflora of broiler chickens as influenced by cereal grains and microbial enzyme supplementation. J. Anim. Physiol. Anim. Nutr. 93(5): 647-658.

Svihus, B. and H. Hetland. 2001. Ileal starch digestibility in growing broiler chickens fed a wheat-based diet is improved by mash feeding, dilution with cellulose or whole wheat inclusion. Br. Poult. Sci. 42:633-637. 